\title{
Online Learning during the Covid-19 Pandemic: A Web-Based Survey of Undergraduate Students of Pokhara University, Nepal

\author{
Salina Khatri ${ }^{1}$, Santosh Kumar Gurung ${ }^{2 *} \odot$, Ramkrishna Chapagain ${ }^{2} \odot$, \\ Sunita Sharma ${ }^{3}{ }^{\oplus}$, Nim Bahadur Dangi ${ }^{3}{ }^{\circledR}$
}

Undergraduate Student, School of Business, Pokhara University

2 Lecturer, School of Business, Pokhara University

3 Lecturer, School of Health and Allied Sciences, Pokhara University

* Corresponding Author (f18santoshg@iima.ac.in)

Received: 28 August, 2021

Revised: 21 October, 2021

Accepted: 23 November, 2021

Published: 25 December, 2021

How to cite this paper:

Khatri, S., Gurung, S.K., Chapagain, R.K., Sharma, S., Dangi, N.B. (2021). Online learning during COVID-19 Pandemic. A web-based survey of undergraduate students of Pokhara University, Nepal. Quest Journal of Management and Social Sciences, 3(2), pp. 245-255.

Copyright (C) 2021 by authors and Quest Journal of Management and Social Sciences.

This work is licensed under a Creative Commons Attribution-Non Commercial-No Derivatives 4.0 International License.

https://creativecommons.org/ licenses/by-nc-nd/4.0/

\section{Abstract}

Background: COVID-19 pandemic has forced educational institutions throughout the world to shut, putting academic calendars in jeopardy. To continue the academic activities, most educational institutions have switched to online mode of learning.

Objective: The study aims to identify the perception and attitude of the undergraduate students towards e-learning during Covid-19 pandemic, to determine the online learning characteristics of the students across different academic year, and to explore the factors that influence the online learning activities of the students.

Method: The study employed a descriptive cross-sectional research design. The selfadministered questionnaire was developed after a thorough assessment of the literature and consultation with subject specialists, and it included demographic information about the research participants, as well as their perceptions and attitudes regarding online classes. The questionnaire was created on Google Forms, and the link was distributed to the students of all the four schools through Viber and Messenger groups. Data was collected online from 300 undergraduate students at Pokhara University in Nepal. Descriptive statistics (frequency, percentage) and inferential statistics were used to examine and interpret the data. The chi-squared test was employed to analyze the link between the student's online learning characteristics and academic year. To explore the characteristics that impact online learning activities, exploratory factor analysis was performed.

Result: The results indicated statistically significant association of online learning characteristics of students of different academic year with availability of alternative power source, internet service, digital platform used and availability of basic computer skill and continuation of online class. Majority of the students evinced a positive attitude towards online classes. Online learning was deemed advantageous since it offered learners with flexibility and convenience. Furthermore, teachers devote appropriate time for studying, motivating students to learn, and emphasizing student-centered learning. However, students are dissatisfied with the teachers' online teaching skills owing to a lack of training and familiarity with modern information technology.

Conclusion: The study concluded that although students reported positive attitude towards online classes, there are serious challenges of power backup or alternative power supply, poor connectivity, unfamiliarity of digital platforms and poor ICT skills among students. Teachers need to be trained properly for the effective and productive teaching and learning along with proper handling of digital platforms. The school/ college/ university must have a well-established IT infrastructure for the smooth operation of online classes.

Paper Types: Research Paper

Key Words: Online learning, Perception, Effectiveness, Students, COVID-19 pandemic

JEL Classification: A22, I29 


\section{Introduction}

World Health Organization (WHO) declared the severe acute respiratory syndrome coronavirus 2 (SARS-CoV-2) outbreak as a 'public health emergency of international concern' on January 30, 2020, and declared the outbreak the Covid-19 pandemic on March 11, 2020 (WHO, 2020). Since then, the Covid-19 pandemic has significantly disrupted all aspects of human life, including education. As a result of this, school and university closures affected more than 1.5 billion students worldwide (UNESCO, 2020). Many schools and universities shifted from traditional classroom teaching to virtual teaching methods.

Soon after the decision of the government to implement a nationwide lockdown on March 24, 2020, educational institutions in Nepal shifted to an online teaching environment from the usual face-to-face one. The main concern, however, is the effectiveness of learning, for example, the effectiveness of content delivery through available online platforms, the familiarity of teachers and students with the use of recent available technical devices and digital platforms. As a result of nationwide lockdown, teachers were forced to conduct online classes, mainly through Zoom, Google Meet and other available online platforms. This growing trend of virtual education in the Nepalese education system has raised awareness of online classes to Nepalese teachers, students and parents. (Pokharel,2020; Gyawali,2020).

Students were not able to attend the online classes effectively due to poor internet connection, unavailability of technical staff, slow speed of internet and high internet traffic were encountered. Training for faculties conducting online classes was regarded as effective for the smooth operation of the class (Gupta et al., 2020). Online learning was beneficial but students felt traditional lectures were more useful than online lectures. The students encountered difficulty in concentration and very few students got the chance of using the excellent internet during classes. Despite all these issues, students had a positive attitude towards e-learning (Bhattarai et al., 2021).

Some studies show that students prefer e-learning because of the freedom to communicate with teachers and peers, the flexibility of space and time for searching learning resources. They had a similar learning experience as they did in a physical classroom and through easy access to information, usefulness, self-efficacy, and ease of use (Khan et al., 2021). Studies on students' perception of online learning in medical schools revealed dissatisfaction with the virtual learning methods inhibited by a lack of practical classes, which they believed could not be obtained through online learning (Adhikari et al., 2020). Few other studies revealed that lack of confidence in using technology, technical problems and distractions at home, repetitive class, lack of interaction, limited collaboration with peers, and lack of skill among educators were among the challenges faced by students (Poudel et al., 2021).

Past studies also revealed that the majority of the participants received formal education or training to use a computer and agreed that online contents were effective and relevant. Moreover, interrupted internet connection and unfeasible practical natured courses were the major obstacles in online learning. However, the majority of the participants also perceived face-to-face learning as more effective than online learning. Satisfied with the teachers' preparation, the respondents realized the online learning is informative, interesting and enjoyable, useful for distance education and productive, relevant during the Covid-19 and it tailors the learner's needs (Rana et al., 2021). Students faced problems in internet connectivity because of the unpredictable load-shedding of electricity. In some cases, students need revision of certain topics covered through the online mode of delivery and can come back to regular classes (Tuladhar et al., 2020). However, Acharya (2020) found the online mode of delivery was perceived, particularly in the initial stages, as impractical and not feasible because students faced unexpected interruptions in internet connectivity and power supply. Acharya (2020) also reported that students were uncomfortable with online courses and students were not regular. However, in course of time, both teachers and students gained experiences and developed skills and gradually they became familiar with the online learning modes. 
Few other studies found that online lectures are not always feasible as per their time. Students agree that the software used for online learning is user-friendly, but internet connectivity, sometimes, hampers the smooth operation of online classes. Similarly, students strongly disagree with the continuation of online classes and wait for face-to-face classes to start. This indicates that online classes are less effective than traditional lectures (Adhikari et al., 2020). Some other studies such as Sharma et al. (2021) show that students found online lectures helpful because the digital classroom application was helpful in communication. Students felt comfortable exploring online tutorials and reported that online tutorials needed further improvement to support their learning. They favored traditional face-to-face lectures over online lectures because they found online classes difficult to concentrate on. They thought the online tutorials should replace traditional lectures and live demonstrations. However, they preferred a combination of traditional teaching and online tutorials i.e., a blended mode of learning (Sharma et al., 2021).

In medical research, medical students perceived online classes negatively. Students perceived traditional face-to-face teaching as more effective than online learning. However, students believed that the online learning system is easy to use and it is easy to manage study time effectively (Koirala et al., 2020). Other studies found that students need to be updated with the latest technology, an online class is effective, they got enough time to study on their own, and it enhances self-studying habits (Sharma et al.,2020).

The Covid-19 pandemic has changed classrooms to virtual mode, an entirely new practice in Nepal. In addition, all higher education institutions (HEIs) in Nepal do not have ICT infrastructure and adequate preparation for online education and learning. Moreover, teachers and students are not mentally and technically prepared for teaching and learning online. In this regard, it is very crucial to assess the opinion and viewpoint of students on the virtual modes of learning to teaching and learning. Previous studies have evaluated and identified students' perceptions and attitudes towards e-learning during the Covid-19 pandemic. Most of the studies are from the context of medical and health science in Nepal (Poudel et al., 2021; Khan et al., 2021; Gupta et al., 2020; Rana et al., 2021; Bhattarai et al., 2021; Tuladhar et al., 2020; Koirala et al., 2020; Adhikari et al., 2020). However, none of these studies provide a clear picture of students' perception of online-class during the Covid-19 pandemic regarding students pursuing engineering, management and social science courses in Nepal. The study is even more relevant considering that the approach of online learning is an entirely new practice. Further, numerous studies in the medical education sector have been carried out in Nepal but this study considers the effectiveness of online learning in other streams of education such as humanities and social sciences, management, engineering and health sciences. In this line, the present study examines the perception of the undergraduate students towards e-learning during the Covid-19 pandemic, determines the online learning characteristics of the students across different academic years, and explores the factors that influence the online learning activities of the students. Further part of this study is organized as second section covers research methods followed by discussion in section three and finally section four concludes the study.

\section{Research Methods}

The study is based on a descriptive cross-sectional study design. The respondents of this study were selected based on consecutive sampling from undergraduate students of constituent schools of Pokhara University, Nepal. The data collection was performed online by preparing a self-administered Google form questionnaire after a thorough assessment of the literature and consultation with the subject experts and the link of the questionnaire was shared in the Viber and Messenger groups of all four schools. There were three sections in the questionnaire. Section 1 intended to gather information related to the socio-demographic characteristics of the students. Section 2 of the questionnaire assessed students' online learning characteristics. Section 3 explored perception and factors that influence online learning. 
The samples of 300 students responded from various constituent schools of Pokhara University from January to March 2021. A five-point Likert scale was used to measure students' perception of online classes. Different statistical tools like descriptive statistics, chi-square test, and exploratory factor analysis, etc. have been used for analyzing the data in SPSS.

\section{Data Analysis and Results}

\section{Socio-Demographic Characteristics}

Table 1 describes the demographic profile of the respondents classified based on their marital status, gender, age group, faculty of study, academic year, and current place of residence of the sample respondents. Table 1 reveals that the majority of the sample respondents $(56.3 \%)$ were females whereas $43.7 \%$ were males. In terms of age group, $64.0 \%$ of the respondents were $21-23$ years; $29.3 \%$ in the age group $18-20$ years and $6.7 \%$ of students in the age group of $23-27$ and the majority $(95.0 \%)$ were unmarried. Similarly, as presented in Table 1, 33.3\% of respondents were in the first year, $21.0 \%$ are in the second year, $31.7 \%$ are in the third year, and $14.0 \%$ are in the fourth year respectively. Likewise, $29.7 \%$ of the total respondents were from business management courses, $29.0 \%$ from the courses of engineering, $25.7 \%$ from health and allied sciences, and the rest $15.7 \%$ were from humanities and social science streams. Moreover, the majority (56.3\%) of the respondents currently reside in the urban area, $30.7 \%$ reside in the semi-urban area and very few $13.0 \%$ reside in the rural area.

Table 1: Socio-Demographic Profile of Respondents

\begin{tabular}{llll}
\hline Variables & Categories & Frequency & Percent \\
\hline Marital Status & Married & 15 & 5 \\
& Unmarried & 285 & 95 \\
& Total & $\mathbf{3 0 0}$ & $\mathbf{1 0 0}$ \\
\hline Gender & Male & 131 & 43.7 \\
& Female & 169 & 56.3 \\
& Total & $\mathbf{3 0 0}$ & $\mathbf{1 0 0}$ \\
\hline Year of study & 1st year & 100 & 33.3 \\
& 2nd year & 63 & 21 \\
& 3rd year & 95 & 31.7 \\
& 4th year & 42 & 14 \\
& Total & $\mathbf{3 0 0}$ & $\mathbf{1 0 0}$ \\
\hline Faculty of study & School of Business & 89 & 29.7 \\
& School of Engineering & 87 & 29 \\
& School of Health and Allied Science & 77 & 25.7 \\
& School of Development and Social Engineering & 47 & 15.7 \\
& Total & $\mathbf{3 0 0}$ & $\mathbf{1 0 0}$ \\
\hline Age & 18 to 20 & 88 & 29.3 \\
& 21 to 23 & 192 & 64 \\
& 23 to 27 & 20 & 6.7 \\
& Total & $\mathbf{3 0 0}$ & $\mathbf{1 0 0}$ \\
\hline Variables & Categories & Frequency & Percent \\
\hline & & &
\end{tabular}




\begin{tabular}{llll}
\hline Current place of residence & Urban area & 169 & 56.3 \\
& Rural area & 39 & 13 \\
& Semi- urban area & 92 & 30.7 \\
& Total & $\mathbf{3 0 0}$ & $\mathbf{1 0 0}$ \\
\hline
\end{tabular}

\section{Online Learning Characteristics of Respondents}

Table 2 presents the online learning characteristics of students amidst the Covid-19 pandemic. Of 300 respondents, the majority $(84.0 \%)$ of respondents have basic computer skills required for online classes, whereas $81.3 \%$ did not have experience of online classes before the pandemic. Similar findings were observed in several previous studies (Koirala et al., 2020; Poudel, Tripathi \& Ghimire, 2021; Gupta et al., 2020; Baczek et al., 2021; Sasmal \& Roy, 2021; Khan et al, 2021).

Similarly, the majority (47.7\%) were engaged in the online class for 3-4 hours a day and $64.3 \%$ did not share devices with other family members. This indicates that students have access to personal devices such as smartphones and laptops. This finding is similar to previous studies (Sasmal \& Roy, 2021; Nuraeni, et al, 2020; Gismalla et al, 2021; Khan et al,2021). Similarly, the most commonly used internet service among students was found to be world link (37.3\%). Likewise, more than half $(51.0 \%)$ of respondents used Microsoft Teams as their digital platform for online classes. The majority $(59.3 \%)$ of the respondents had got the access to internet service 24 hours a day (Gismalla et. al, 2021 ) and $65.0 \%$ of respondents reported that they were not satisfied with the speed of their internet service (Adhikari et al., 2020; Koirala et al., 2020; Azhari \& Kurniawati, 2020). Although the majority $49.7 \%$ reported knowledge of basic ICT skills, they were not fluent. In addition, the majority (81.3\%) of the respondents faced interrupted online class due to lack of power backup (Adhikari et al., 2020; Koirala et al., 2020; Khan et al, 2021) and the majority (74.7\%) responded that they did not get any disturbances during the online classes from their family members. Furthermore, $58.0 \%$ got access to partially available alternative sources to join the online classes and $57.3 \%$ of the respondents did not want the continuity of online learning beyond the pandemic (Adhikari et al., 2020; Koirala et al., 2020).

Table 2: Online Learning Characteristics of Respondents

\begin{tabular}{|c|c|c|c|}
\hline Variables & Categories & Frequency & Percent \\
\hline \multirow{3}{*}{ Basic computer skill before Covid- } & Yes & 252 & 84 \\
\hline & No & 48 & 16 \\
\hline & Total & 300 & 100 \\
\hline \multirow{3}{*}{ Experience of online class before Covid- } & Yes & 56 & 18.7 \\
\hline & No & 244 & 81.3 \\
\hline & Total & 300 & 100 \\
\hline \multirow{5}{*}{ Hours of engagement in online learning } & Up to 2 hours & 123 & 41 \\
\hline & 3 to 4 hours & 143 & 47.7 \\
\hline & 5 to 6 hours & 28 & 9.3 \\
\hline & 7 and more hours & 6 & 2 \\
\hline & Total & 300 & 100 \\
\hline \multirow{3}{*}{ Sharing of device with other family members } & Yes & 107 & 35.7 \\
\hline & No & 193 & 64.3 \\
\hline & Total & 300 & 100 \\
\hline Variables & Categories & Frequency & Percent \\
\hline https://doi.org/10.3126/qjmss.v3i1.41579 & 249 & & QJMSS (2 \\
\hline
\end{tabular}




\begin{tabular}{|c|c|c|c|}
\hline \multirow{8}{*}{ Internet service provider used for online learning } & Ncell data & 18 & 6 \\
\hline & Nepal telecom data & 18 & 6 \\
\hline & Classic tech internet & 12 & 4 \\
\hline & World link & 112 & 37.3 \\
\hline & NT Fiber net & 33 & 11 \\
\hline & ADSL & 26 & 8.7 \\
\hline & Others & 81 & 27 \\
\hline & Total & 300 & 100 \\
\hline \multirow{3}{*}{ Internet available $24 \times 7$} & Yes & 178 & 59.3 \\
\hline & No & 122 & 40.7 \\
\hline & Total & 300 & 100 \\
\hline \multirow{3}{*}{ Satisfaction with the speed of the internet } & Yes & 105 & 35 \\
\hline & No & 195 & 65 \\
\hline & Total & 300 & 100 \\
\hline \multirow{5}{*}{ Platform used for the online class } & Zoom & 139 & 46.3 \\
\hline & Google classroom & 1 & 0.3 \\
\hline & Google Meet & 7 & 2.3 \\
\hline & Microsoft Team & 153 & 51 \\
\hline & Total & 300 & 100 \\
\hline \multirow{4}{*}{ Basic ICT skills required } & Yes fluent & 113 & 37.7 \\
\hline & Yes but not fluent & 149 & 49.7 \\
\hline & No & 38 & 12.7 \\
\hline & Total & 300 & 100 \\
\hline \multirow{3}{*}{ Power supply status at home } & $\begin{array}{l}\text { Continuous with } \\
\text { backup }\end{array}$ & 56 & 18.7 \\
\hline & Interrupted & 244 & 81.3 \\
\hline & Total & 300 & 100 \\
\hline \multirow{3}{*}{ Disturbance from a family member during class } & Yes & 76 & 25.3 \\
\hline & No & 224 & 74.7 \\
\hline & Total & 300 & 100 \\
\hline \multirow{4}{*}{ Have all resources to join the online class } & Available all the time & 116 & 38.7 \\
\hline & Partially available & 174 & 58 \\
\hline & Not available & 10 & 3.3 \\
\hline & Total & 300 & 100 \\
\hline \multirow{3}{*}{ Continue online class even after Covid-19 } & Yes & 128 & 42.7 \\
\hline & No & 172 & 57.3 \\
\hline & Total & 300 & 100 \\
\hline
\end{tabular}




\section{Online Learning Characteristics of Students of Pokhara University across Different Academic Years}

Table 3 depicts the online learning characteristics of students of Pokhara University across different academic years. The majority (174) of respondents reported partial availability of alternative power sources during online classes; 66 first-year and 52 third-year students had the most difficulties in taking online classes smoothly because of interrupting alternative power sources. Similarly, during the online class, the majority (112) of the students used the world link internet service and more than half of the respondents (178) reported they had access to the internet 24 hours a day, but the majority (195) reported they were dissatisfied with the speed of the internet. The majority of respondents used Microsoft Teams (153) and Zoom (139) as their digital platform for online classes. This study confirmed the findings of several previous studies (Nuraeni, et al, 2020; Khan et al,2021). The study also found that the majority $(51.0 \%)$ of the respondents used Microsoft Teams as the digital platform. The study discovered that that the previous experience of digital platforms and the training before formal e-learning were important considerations (Kanwal \& Rehman, 2017, Khan et al, 2021). Although most of the respondents (149) reported good knowledge of basic ICT skills, they were not fluent. In addition, a majority (244) of the respondents had interrupted online classes because of a lack of power backup. Furthermore, the majority (172) of the respondents do not want to continue online learning. The study showed a statistically significant association of online learning characteristics of students of different academic years with the availability of alternative power sources, tools used for online classes and availability of basic computer skills. The present study confirms the findings of previous studies that internet service, the digital platform used for online classes and competence of IT skills proved to be effective for online learning (Muthuprasad, et al., 2020, Acharya, 2020).

However, the current study found dissatisfaction with the online teaching skills of teachers because classes were unstructured, the teacher had no good service quality, and they did not provide sufficient learning materials required. The reason behind this could be due to a lack of ICT knowledge, unfamiliarity with the digital platform they were using, and no prior training to teachers (Kula \& Nayak, 2020).

Table 3: Online Learning Characteristics of Students of Pokhara University Across Different Academic Years

\begin{tabular}{llcccccc}
\hline $\begin{array}{c}\text { Online Learning } \\
\text { Characteristics }\end{array}$ & \multicolumn{1}{c}{ Categories } & $\mathbf{1}^{\text {st }} \mathbf{Y r}$ & $\mathbf{2}^{\text {nd }} \mathbf{Y r}$ & $\mathbf{3}^{\text {rd }} \mathbf{Y r}$ & $\mathbf{4}^{\text {th }} \mathbf{Y r}$ & Total & P-value \\
\hline \multirow{3}{*}{ Alternative source of power } & Available all the & 31 & 19 & 40 & 26 & 116 & \\
& $\begin{array}{l}\text { time } \\
\text { Partially available }\end{array}$ & 66 & 41 & 52 & 15 & 174 & $0.022^{* *}$ \\
& Not available & 3 & 3 & 3 & 1 & 10 & \\
\hline & Ncell data & 10 & 4 & 3 & 1 & 18 & \\
& Nepal telecom data & 8 & 3 & 4 & 3 & 18 & \\
& Classic tech internet & 6 & 1 & 2 & 3 & 12 & \\
Internet service provider & World link & 27 & 26 & 42 & 17 & 112 & 0.28 \\
& NT Fiber net & 16 & 3 & 10 & 4 & 33 & \\
& ADSL & 6 & 7 & 9 & 4 & 26 & \\
& & 27 & 19 & 25 & 10 & 81 & \\
\hline \multirow{2}{*}{24 hours internet available } & Yes & 52 & 37 & 60 & 29 & 178 & \multirow{2}{*}{0.21} \\
& N0 & 48 & 26 & 35 & 13 & 122 & \\
\hline
\end{tabular}




\begin{tabular}{llcccccc}
\hline \multirow{2}{*}{ satisfied with speed } & Yes & 36 & 15 & 36 & 18 & 105 & 0.17 \\
& N0 & 64 & 48 & 59 & 24 & 195 & \\
\hline \multirow{4}{*}{$\begin{array}{l}\text { Digital platform used for } \\
\text { online class }\end{array}$} & Goom & 56 & 38 & 28 & 17 & 139 & \\
& Google classroom & 0 & 0 & 1 & 0 & 1 & $0.006^{* * *}$ \\
& Microsoft Team & 42 & 24 & 64 & 23 & 153 & \\
\hline \multirow{4}{*}{ Basic ICT skills } & Yes fluent & 30 & 21 & 36 & 26 & 113 & \\
& Yes, but not fluent & 52 & 32 & 52 & 13 & 149 & $0.007^{* * *}$ \\
& Not & 18 & 10 & 7 & 3 & 38 & \\
\hline \multirow{5}{*}{ Power Supply Status } & Continuous with & 18 & 11 & 18 & 9 & 56 & 0.95 \\
& backup & 82 & 52 & 77 & 33 & 244 & \\
\hline Continue Online Teaching & Interrupted & 40 & 24 & 41 & 23 & 128 & \multirow{2}{*}{0.34} \\
and Learning & Yes & 60 & 39 & 54 & 19 & 172 & \\
\hline
\end{tabular}

\section{Factors influencing online learning activities of students}

Table 4 shows the result of factor analysis that the teachers of Pokhara University were very laborious to online teaching. They gave time to students, motivated them to learn, provided well-updated content and always focused on student-centric learning. The students also had a happy online learning experience as they have the view that online learning had saved their time, gave more flexibility, and was more convenient than a physical class which is in line with the study results of Gautam \& Gautam, 2021, where $61 \%$ believe that online teaching mode becomes more effective because it is flexible in terms of time, the availability of teaching material. The study findings of preference to online classes over traditional classes contradict the findings of Sasmal \& Roy, 2021, where $80.43 \%$ agreed to prefer traditional classroom sessions over e learning because of difficulty in conducting practical classes online. Similarly, the study found a positive attitude towards using the online learning, which is similar to the study results of Teuku Azhari \& Kurniawati, 2020; Gismalla, 2021.

However, students had some dissatisfaction with the online teaching skills of the instructor. They reported that classes were unstructured, the teacher did not have good service quality at online classes, and they did not provide materials required to students. The study found that online learning activities are not practical because students are not familiar with the online learning model (Purwadi et al., 2021). Online lectures were very ineffective because not all students listened well to what lecturers conveyed. This condition encouraged the lack of students' understanding of the material provided by lecturers. Students experienced failure in covering material that comes from the teacher. Lecturers did not provide more detailed explanations when online learning was carried out, unlike face-toface learning. The findings indicated that teachers lack proper training and familiarity with current information technology. So, this study confirmed the finding of Sasmal and Roy (2021) that 57.19\% of participants responded that they felt teachers required special training for effective e-learning.

Table 4: Factors Influencing Online Learning Activities of Students

\begin{tabular}{cccc}
\hline Items & $\begin{array}{c}\text { Instructors' } \\
\text { labor }\end{array}$ & $\begin{array}{c}\text { class } \\
\text { experience }\end{array}$ & $\begin{array}{c}\text { Instructor's } \\
\text { ICT skills }\end{array}$ \\
\hline
\end{tabular}

Instructor response to your assignment within a definite 0.738

time.

The course instructor was accessible to answer a 0.72 question or give feedback. 


\begin{tabular}{|c|c|c|c|}
\hline Items & $\begin{array}{c}\text { Instructors' } \\
\text { labor }\end{array}$ & $\begin{array}{c}\text { class } \\
\text { experience }\end{array}$ & $\begin{array}{l}\text { Instructor's } \\
\text { ICT skills }\end{array}$ \\
\hline $\begin{array}{l}\text { The interaction between you and your instructors are } \\
\text { well established. }\end{array}$ & 0.641 & & \\
\hline $\begin{array}{l}\text { Instructors encourage other students to collaborate with } \\
\text { you on the syllabus or course reading material. }\end{array}$ & 0.599 & & \\
\hline $\begin{array}{l}\text { Instructors have met the expectation of your during the } \\
\text { online class. }\end{array}$ & 0.554 & & \\
\hline $\begin{array}{l}\text { The content of the course in the online classes is } \\
\text { satisfactory. }\end{array}$ & 0.509 & & \\
\hline The facilities provided were up to your expectations. & 0.455 & & \\
\hline $\begin{array}{l}\text { Learning online makes you save time rather than having } \\
\text { to attend a class. }\end{array}$ & & 0.784 & \\
\hline $\begin{array}{l}\text { The online class is convenient in comparison to a } \\
\text { physical class. }\end{array}$ & & 0.675 & \\
\hline $\begin{array}{l}\text { Learning online gives you the flexibility to adjust your } \\
\text { learning time. }\end{array}$ & & 0.458 & \\
\hline Instructors provide us with good service quality. & & & -0.841 \\
\hline Course material is presented in a good structure. & & & -0.779 \\
\hline $\begin{array}{l}\text { The instructor provides the slide and videos related to } \\
\text { the course. }\end{array}$ & & & -0.311 \\
\hline
\end{tabular}

Note: Extraction Method: Principal Axis Factoring.

Rotation Method: Oblimin with Kaiser Normalization.

Rotation converged in 8 iterations.

\section{Conclusion}

Despite the majority of students did not have adequate ICT skills; no prior experience of online learning; had inadequate internet connectivity and power backup, the majority of students had a positive attitude toward online classes. Online learning was found to be useful since it gave flexibility and convenience for learners, and teachers supply slides and videos while teaching, allowing students to learn more rapidly. They are, however, dissatisfied with the teacher's online teaching abilities. Most students reported that classes were unstructured, that teachers did not provide good service quality in online classes, that interaction between teachers and students was limited, that they did not assist students as per the need, and that they did not provide required materials to students. As a result, instructors must be appropriately prepared for successful and productive teaching and learning, as well as proper use of digital platforms. The nature of data collected in this study was cross-sectional, future research can use a longitudinal study to handle this limitation. Further, the data was collected from one type of respondents only, that is, the students. Future research can also include the perspectives of teachers and policymakers to have more generalization of the results. This study is limited to evaluating the effectiveness of students, so in the future, the performance of teachers can be evaluated with similar kinds of conditions.

\section{Conflicts of Interest}

The authors declare that they have no conflicts of interest. 


\section{References}

Acharya, A., Poudyal, N., Lamichhane, G., Aryal, B., Bhattarai, B. R., Adhikari, B., \& Parajuli, N. (2020). Internetbased Online Higher Education in Nepal Amidst Covid-19. https://doi.org/10.35542/osf.io/r85bc

Acharya, S. (2020). Stress in the students after lockdown due to outbreak of the Corona virus (Covid-19). BSN 4 , (Covid 19), 1-15.

Adnan, M., \& Anwar, K. (2020). Online learning amid the Covid-19 pandemic: Students' perspectives, Journal of Pedagogical Sociology and Psychology, 2(1). http://www.doi.org/10.33902/JPSP. 2020261309

Adhikari, P., Paudel, S., Pandey,R.,Parajuli, A., \& Pyakuryal, A.(2020). Effectiveness of e-learning during the Covid-19 pandemic among the undergraduate medical students in Nepal: An online survey. Journal of Pharmacy Practice and Community Medicine. 6 (3), 40-43

Almahasees, Z., Mohsen, K., \& Amin, MO. (2021). Faculty's and students' perceptions of online learning during Covid-19. Front. Educ. 6:638470. doi: 10.3389/feduc.2021.638470.

Azhari, T., Kurniawati. (2020). students' perception on online learning during the Covid-19 pandemic: A case study of Universitas Malikussaleh students. Advances in Social Science, Education and Humanities Research. 495. Proceedings of the International Conference on Social Science, Political Science, and Humanities (ICoSPOLHUM, 2020).

Baczek, M., Zaganczyk-Baczek, M., Szpringer, M., Jaroszynski, A., \& Wozakowska-Kap łon, B.(2021). Students’ perception of online learning during the Covid-19 pandemic: A survey study of Polish medical students. Medicine 2021;100:7(e24821).

Bhattarai, B., Gupta, S., Dahal,S., Thapa, A., \& Bhandari, P. (2021). Perception of online lectures among students of a medical college in Kathmandu. Journal of Nepal MedicalAssociation, 59(235), 234-8.

Gautam, D., \& Gautam, P. (2020). Transition to online higher education during the Covid-19 pandemic: Turmoil and way forward to the developing country of South Asia- Nepal, Journal of Research in Innovative Teaching \& Learning, 14(1), 2021 pp. 93-111 Emerald Publishing Limited 2397-7604 DOI 10.1108/JRIT10-2020-0051

Gismalla, M.D.A.,Mohamed, M.S., Omaima Salah O Ibrahim, O.S.O., Elhassan, M.M.A \& Mohamed, M.N.E. (2021). Medical students' perception towards E-learning during the Covid- 19 pandemic in a high burden developing country. BMC Medical Education, 21:377, https://doi.org/10.1186/s12909-021-02811-8.

Gupta, A., Shrestha, RM., Shrestha, S., Acharya, A., \& Pandey, N. (2020). Perception of BDS students of Kathmandu University on online learning during the Covid-19 pandemic. Orthodontic Journal of Nepal, 10(2), Covid-19 Special Issue, https://www.nepjol.info/index.php/OJN/article/view/31064.

Kanwal, F., \& Rehman, M. (2017). Factors affecting e-Learning adoption in developing countries: Empirical evidence from Pakistan's Higher Education Sector. IEEE Access, 5, 10968-10978.

Khan, M.A., Vivek, Nabi, M.K., Khojah, M., \& Tahir, M. (2021). Students' perception toward e-Learning during the Covid-19 pandemic in India: An empirical study. Sustainability, 13 (57). https://dx.doi.org/10.3390/ su13010057.

Koirala, D., Silwal, M., Gurung, S., Bhattarai, M., \& KC, V.K. (2020). Perception towards online classes during the Covid-19 among nursing students of a medical college of Kaski District, Nepal. Journal of Biomed Research Environment Science, 1(6), 249-255.

Kulal, A., \& Nayak, A. (2020). A study on perception of teachers and students toward online classes in Dakshina Kannada and Udupi District, Asian Association of Open Universities Journal, 15(3), pp. 285-296. https:// doi.org/10.1108/AAOUJ-07-2020-0047.

Mahat, D. (2021). Students' perception towards online-class during the Covid-19 pandemic. International Research Journal of MMC (IRJMMC), 2(1), ISSN 2717-4999 (Online) 2717-4980 (Print), https://doi.org/10.3126/ irjmmc.v2i1.35127.

Molla, R. (2020). Microsoft, Google, and Zoom are trying to keep up with demand for their now freework-fromhomesoftware. Vox,3-7.Retrieved from https://www.vox.com/recode/2020/3/11/21173449/microsoftgoogle-zoom-slack-increaseddemand-free-work-from-home-software 
Nepal, S., Atreya, A., Menezes, R.G., \& Joshi, R.R. (2020). Students' perspective on online medical education amidst the Covid-19 pandemic in Nepal. Nepal Health Research Council, 18(48), 551-5, DOI: https://doi. org/10.33314/jnhrc.v18i3.2851.

Nuraeni, L., Purwasih, R., \& J Mutakim, J. (2020). IKIP Siliwangi student's perceptions of online teaching and learning process during the Covid-19 pandemic? Journal of Physics: Conference Series, 2nd ISAMME 2020, IOP Publishing, 657 (2020) 012084, doi:10.1088/1742-6596/1657/1/012084.

Poudel, P., Tripathi, G., \& Ghimire, R. (2021). Medical and nursing students' perception and experience of virtual classrooms during the Covid-19 pandemic in Nepal. Interdisciplinary Journal of Virtual Learning Medical Science, 12(2):85-96, https://doi.org/10.30476/ ijvlms.2021.89644.1076.

Purwadi, Saputra, W. N. E., Wahyudi, A., Supriyanto, A., Muyana, S., Rohmadheny, P. S., Ariyanto, R. D., \& Kurniawan, S. J. (2021). Student perceptions of online learning during the Covid-19 pandemic in Indonesia: A study of phenomenology. European Journal of Educational Research, 10(3), 1515-1528. https://doi.org/10.12973/eu-jer.10.3.1515.

Rana, S., Garbuja, C.K., \& Rai, G. (2021). Nursing students' perception of online learning amidst the Covid-19 pandemic. Journal of Lumbini Medical College, 9(1).

Sasmal, S., \& Roy M. (2021). Perception of undergraduate nursing students regarding e-learning during the Covid-19 pandemic in West Bengal. International Journal of Community Medical Public Health, 8, 18928.

Sharma, K., Deo, G., Timalsina, S., Joshi, A., Shrestha, N., \& Neupane, H. C. (2020). Online learning in the face of the Covid-19 pandemic: Assessment of students' satisfaction at Chitwan Medical College, Nepal. Kathmandu University Medical Journal., Covid-19 Special Issue, 70(2), 38-45, https://doi.org/10.3126/ kumj.v18i2.32943.

Sharma, N., Bhusal, C. K., Subedi, S., \& Kasarla, R. R. (2021). Perception towards online classes during the Covid-19 among MBBS and BDS students in a Medical College of Nepal: A descriptive cross-sectional study. Journal of Nepal Medical Association, 59(235), https://doi.org/10.31729/jnma.5348.

Tuladhar, S. L., Pradhan, D., Parajuli, U., Manandhar, P., \& Subedi, N. (2020). Study on the effectiveness of online classes for undergraduate medical and dental students of Gandaki Medical College during the Covid-19 pandemic in Nepal. Orthodontic Journal of Nepal,10(2) Covid-19 Special Issue, https://www.nepjol.info/ index.php/OJN/article/view/31146/24669.

T, Muthuprasad., S, Aiswarya., Aditya, K.S., \& Jha, Girish K. (2020). Students' perception and preference for online education in India during the Covid-19 pandemic. Available at SSRN: https://ssrn.com/abstract=3596056 or http://dx.doi.org/10.2139/ssrn.3596056

UGC (2018). Education management information system: Report for higher education 2018/19, University Grants Commission (UGC), Bhaktapur, Nepal, https://www.ugcnepal.edu.np/uploads/upload/1BmXHe.pdf

UNESCO. (2020). Global monitoring of school closures caused by Covid-19, available at https://en. unesco.org/ covid19/education response.

WHO. (2020). Coronavirus disease (Covid-19) situation report, available at https://www.who.int/docs/defaultsource/coronaviruse/situation-reports/20200510COVID-19-sitrep-111.pdf? sfvrsn51896976f_2. 